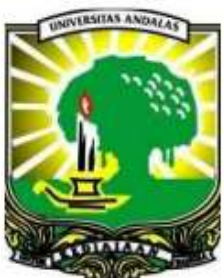

Available online at http://ijasc.pasca.unand.ac.id

International Journal of Agricultural Sciences Graduate Program Universitas Andalas

Journal homepage: http://ijasc.pasca.unand.ac.id

\title{
Implementation of Integrated Livestock Development as an Effort to Eradicate Poverty in Central Aceh District
}

\author{
Hendra Saputra $^{a *}$, Asdi Agustar $^{b}$, Endry Martius $^{c}$, Maiyestri $^{d}$ \\ ${ }^{a}$ Graduate Program, Universitas Andalas, Kampus UNAND Limau Manis, Padang, West Sumatra 25163, Indonesia

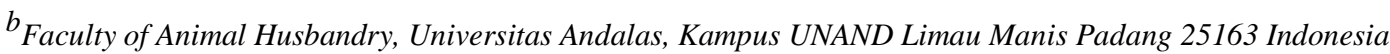 \\ ${ }^{c}$ Faculty of Agriculture, Kampus UNAND Limau Manis, Padang, West Sumatra 25163, Indonesia

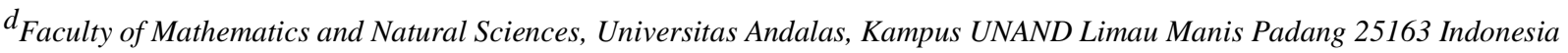

\section{A R T ICLE IN F O \\ Article history: \\ Received 28 July 2017 \\ Received in revised form 27 February \\ 2018 \\ Accepted 15 March 2018}

\section{Keywords:}

Integrated Livestock, Development,

Poverty

\section{A B S T R A C T}

The development of the Ketapang Integrated Livestock Area (KPTK) in Linge Sub-district, Central Aceh District is one of the implementation of local poverty alleviation policies initiated by Central Aceh District Government. This study aims to determine the implementation of KPTK development as an effort to alleviate poverty in Central Aceh District. This research used survey method with data collection in the form of field observation, in-depth interview, and focus group discussion. Data were analysed using descriptive qualitative. This study found that KPTK development has become a commitment to poverty alleviation. This is found in the central Aceh district development planning system. However, in the implementation there are several obstacles to its development, namely: (1) no synchronization of activities/ programs among related sectors; (2) from a technical point of view, some physical facilities such as roads, bridges and housing and settlement enclosures have been damaged and cannot be used anymore.

\section{Introduction}

The United Nations (UN) views poverty as a major challenge for development efforts. Therefore, the UN makes it the main goal of various development policies in many countries. In the World Bank Report (2004), it says that halving of the poor by 2015 is one of the Millennium Development Goals (MDG's).
Similarly, with Indonesia, poverty is still a development issue that should get serious attention. BPS data for 2014 shows that despite the decline in the number of poor people in the last ten years, the absolute number is still quite large, namely 28.55 million people or 11.47 percent of the total population of Indonesia.

The concept of poverty is not only understood to the extent of the economic dimension, which assumes a lack of household income in meeting the

\footnotetext{
* Corresponding author

E-mail address: hendra_saputra8077@yahoo.co.id
} 
minimum basic needs that enable decent living. Furthermore, poverty is a multi-dimensional problem covering social, economic, cultural, political and time and space aspects. Therefore, Wahyuni (2011) argues that the understanding of poverty should be based on the root cause of poverty itself.

In the study of poverty, three conditions are known to be the root cause of poverty: (a) cultural factors, (b) structural factors and (c) natural / natural factors (Rochana, 2010). Cultural poverty centers on the low quality of individuals suspected due to unproductive culture such as lazy behavior and consumptive behavior. On the structural aspect it is seen that poverty occurs and develops due to the unequal economic and political structures. This structural poverty emphasizes the degree of access to various resources as well as unequal power.

These three root causes of poverty are interrelated and exacerbate one another. This condition makes poor people difficult to get out of poverty. Camber (1987) termed the condition as a poverty trap. Thus, poverty alleviation efforts will not work if done partially. Natural, cultural and structural factors are always hooked and therefore must be done simultaneously and comprehensively in an integrated manner.

The results of the literature review found three important components in the effort to alleviate poverty (Papilaya, 2006; Susilo, 2007; Hartarti, 2007; Abustan, 2010; Wahyuni, 2011; IFAD, 2011): (1) redistribution of productive assets to poor households; (2) availability of reliable infrastructure; (3) development and assistance of the poor. However, how can these three main components of poverty alleviation be implemented?

The development of the Ketapang Integrated Livestock Area (KPTK) in Linge Sub-district, Central Aceh District is one of the implementation of local poverty alleviation policies initiated by Central Aceh Regency Government. Implementation of KPTK has been implemented since 2005 , on the area of \pm 400 hectares of settlement. In this area resettlement (resettlement) 100 poor families from 14 districts in Central Aceh district. Poor resettlement begins with the preparation of residential area infrastructure such as residential houses, educational infrastructure, health and environmental infrastructure such as neighborhood roads, public facilities and others.

In the design of each resettled family is given food social security for the first two years. At the time of the family's food needs are guaranteed, then attempted to increase its productivity through agricultural business activities with land \pm 2 hectares per KK and assistance of 15 heads of cows each family. In conducting the business, the settlers at the KPTK are given guidance by placing the extension staff on the site.

The development of KPTK as an effort to improve the welfare of the poor is seen as a comprehensive approach. This is seen from: (1) doing resettlement for the population so that its accessibility to various resources is better; (2) to provide assistance on various factors of production so that it is no longer in a marginal condition; and (3) receive training and guidance so that the culture will transform into productive habits. As a comprehensive approach, the implementation of KPTK is done by involving multi-sectoral Unit Working Units (SKPD) covering various tasks and functions, such as: infrastructure sector; Agricultural sector; The social and labor sectors; And other sectors.

However, after seven years the KPTK has not yet shown optimal results. In the early stages each settler planned to be given food social security for two years but until seven years passed, the government has not been able to stop it because the settlers have not been able to meet the needs of his life from the business undertaken. In addition, the indication of family success varies even though given the same treatment.

The general question raised in this study is: "how is the actual implementation of KPTK development as an implementation of the concept of poverty alleviation comprehensive?

\section{Research Methods}

The research was conducted from November 2015 to October 2016. The research will be conducted at Ketapang Integrated Livestock Area (KPTK) Linge Sub-district, Central Aceh District. The determination of the location of this study is based on the consideration that KPTK is one of the 
policies / programs of the Local Government of Central Aceh in efforts to alleviate poverty with a comprehensive approach. It is called a comprehensive approach because the program component tries to overcome the three aspects causing poverty that is natural, cultural and structural through:

(1) The resssetlement of the poor from the previously marginal location to the KPTK and given 2 ha of land;

(2) Provision of venture capital in the form of seeds (cattle, food crops, and grass), livestock pens, modest houses, and social facilities is an effort to release settlers against the limitations of venture capital. Provision of live allowance (jadup) of Rp. 750.000 / KK / month, for two years so that settlers can meet their needs during the business has not provided enough income. Such conditions are seen as an attempt to overcome structural obstacles;

(3) In conducting its business, settlers receive counseling and assistance from field officers stationed at the KPTK.

The method used in this research is survey method. Technique of collecting data is done by collecting primary data and secondary data. Primary data collection is done by observation method, in-depth interview to key informant, and focus group discussion (Focused Group Discussion). Observation method was conducted in Integrated Livestock Development Zone (KPTK). During the field observation, in-depth interviews were conducted to several key informants. In depth interviews are conducted to stakeholders related to development programs in Integrated Livestock Development Zone (KPTK), ie officials in relevant sectoral agencies / agencies in Central Aceh District. Meanwhile, focus group discussions were also conducted on sectoral sector officials at the Aceh Provincial level in relation to the development of poverty alleviation programs.

\section{Results and Discussions}

\subsection{KPTK Development Policy}

Law no. 22 of 1999 which was then revised by Law no. 32 of 2004 on Regional Government, has changed the pattern of central-local relations that have been thickly paternalistic and centralistic, into a pattern of relationships that are both partnership and decentralized. The law mandates broad (authority) authority, real and responsible proportionally to the regions. This is realized with the arrangement, sharing and utilization of national resources, as well as the balance of central and regional finances in accordance with the principles of regional autonomy, namely: democracy, community participation, attention to regional diversity, equity and justice and the management of potential resources in the region effectively And efficient.

The problem of high poverty and vulnerability of poor people is still the biggest challenge every autonomous region. This condition demands every autonomous region to be pro-active in pursuing poverty alleviation policies, either directly or indirectly. Therefore, poverty alleviation efforts are no longer the responsibility and / or done by the central government alone.

Similarly, Central Aceh District, poverty alleviation is a major problem in development. BPS (2006) shows that the number of poor people in the year 2005 recorded 45 thousand inhabitants or $27.68 \%$ of the population. This poverty rate has placed the 10th district of Aceh Tengah as the district / city with the largest number of poor people from 23 districts / cities in Aceh Province. The high rate of poverty in Aceh Tengah district is suspected to be inseparable from the condition of prolonged conflict and tsunami disaster that hit.

Given the high rate of poverty, the Aceh Tengah District Government is committed to making poverty alleviation a priority in development, as stated in Qanun Kabupaten Aceh Tengah Number 9 of 2009, on the Long Term Development Plan (RPJP) of Aceh Tengah Regency 2005-2025. In the RPJP of Central Aceh District, poverty alleviation efforts are poured into one of its missions: "improving the quality of social welfare" into the 11th mission of 13 missions. This mission is emphasized and elaborated in Qanun Kabupaten Aceh Tengah Number: 4 Year 2007, concerning Medium Term Development Plan (RPJM) of Central Aceh Regency 2007-2012. 
In the RPJM of Central Aceh District Year 2007-2012, set the vision to be achieved in the next five years, namely "Realization of Prosperity and Obsolete Poverty Toward the Community of Central Aceh Prosperous 2012". In an effort to achieve and realize the vision, the Central Aceh Regency Government sets out six missions, to be implemented as well as the duties and functions of each related sector. One of the missions directly related to poverty alleviation efforts is "to strengthen the people's economy in the fields of plantations, horticulture and other agricultural activities, reduce unemployment rates through the opening of employment in various fields".

Within the framework of the Central Aceh District Government policy set forth in the RPJM, the strategy of poverty alleviation in efforts to create a prosperous Central Aceh 2012 society is achieved through the creation of the widest possible employment for the community. The creation of employment is achieved through various policies, namely: (1) acceleration of infrastructure; (2) special/integrated regional programs; (3) increasing agricultural and industrial production; and (4) supply/marketing of production products. The policies that have been formulated, supported are composed of three general programs consisting of programs: (1) community empowerment; (2) the fulfillment of basic needs; and (3) development of social security system.

Judging from the two documents of the regional development planning system (RPJP and RPJM) of Aceh Tengah Regency in line with Law no. 25/2005 on Development Planning System, it can be said that the Government of Central Aceh District has a commitment in alleviating poverty faced in its development. Staying again how this planning is planned, implemented, monitored and evaluated to achieve the goals set.

In implementing the plans contained in the documents RPJP and RPJM, according to Law no. 25/2005 on Development Planning System, mandated to prepare the planning document in the form of Government Work Plan District/City (RKPK). RKPK is a derivative of long-term and medium-term planning includes work plans or strategies that are implementation implementation of the activity. In RKPK Central Aceh District, one of the strategic efforts to eradicate poverty is a priority in the RPJP and RPJM of Central Aceh District.

One of the strategies contained in RKPK Central Aceh District 2005 is through the development of a special / integrated area consisting of six programs and one of them is the development of integrated livestock area. Development of livestock area is targeted until 2012 can accommodate self-employment (shareholding pattern) 600 Head of Family (KK).

Integrated livestock sector development policy is multi-sectoral, meaning that the involvement of various related sectors is required. In RKPK Central Aceh District, there are ten sectors handled by various official agencies in the Central Aceh District Government Work Unit (SKPD). To create synergicity in running the tupoksi from related sectors, every Annual Working Plan (RKT) of official agencies should be based on the planning document above, namely RKPK Central Aceh District. At each Government RKT contains a work plan consisting of planning, implementation and achievement of expected targets.

In the development of special areas / integrated there are six policies, where the development of integrated livestock become one of them. The development of livestock area as stipulated in the strategy of RPJP of Central Aceh Regency, targets the development of integrated livestock area to accommodate 600 household heads in 2005-2009, in 2010-2014 can accommodate 1,200 KK, and the year 2015-2019 targeted livestock as a center of livestock production, and in 2020-2024 livestock area is expected as a center of livestock production processing industry in Central Aceh district. To be able to achieve the targets set, in its implementation required planning, implementa-tion, monitoring and evaluation a comprehensive and measurable level of success and sustainability.

Ministerial Regulation (Permen) of Agriculture Number: 50/Permentan/CT.140/8 /2012, is a reference for planners and decision makers in planning, monitoring and evaluation of agricultural development as described in article (2). In this Permen, there are four steps / stages in the planning process of an integrated agricultural area, namely: (a) determination of location; (b) establishment of 
commodities; (c) settlement of settlers; and (d) preparation of the Master Plan and Action Plan.

\subsection{Initial Planning and Implementation of KPTK Development}

The development of the Ketapang Integrated Livestock Area (KPTK) in Owaq Village, Linge Sub-district, Central Aceh District, became one of the policies mandated in the RPJP and RPJM of Central Aceh District in the effort to overcome poverty to create a prosperous Aceh Tengah community. The main objective of the KPTK development policy is to improve the welfare of the poor who participate in the settlement, through the opening of employment with the provision of various capital of productive assets, facilities and infrastructure and assistance and guidance which are expected to increase the productivity level which further increases the welfare of the settlers themselves.

According to the Regulation of the Minister of Agriculture (Permentan) No. 56 /Permentan /RC.040/11/2016, on Guidelines for the Development of Agricultural Areas, mandated that there are three general stages required in implementing integrated agricultural development policy including KPTK development: (a) Stages of regional planning; (b) the stages of regional development and (c) monitoring and evaluation of regional development.

\subsubsection{Determination of Location and Settlement of KPTK Development}

There is no single theory that can determine where the location of an activity should be chosen. To determine the location of an activity comprehensively, a combination of knowledge and discipline is required. From the results of the literature review, found three criteria that must be met in determining the location of integrated agricultural areas, including KPTK, namely: (a) land suitability with allotment; (b) socio-cultural suitability; And (c) compliance with technical aspects.

In the criteria of "land suitability with the allocation" there are two elements of the compilers are: (a) availability of land with topography and extent appropriate to its needs; And (b) land suitability of Spatial and Regional Plans (RTRW) and other established regulations. Based on the Decree of the Regent of Central Aceh Number: 119 Year 2004, in Ketapang Desa Owaq Village, Linge Sub-district, Central Aceh District is designated as Ketapang Integrated Livestock Development Zone (KPTK) with an area of $\pm 650 \mathrm{Ha}$.

The findings of the KPTK development planning documents as secondary data relate to elements of "availability of land with topography and extent to suit their needs" were found to be important points in establishing KPTK locations. Land availability is one of the considerations of KPTK establishment in Owaq Village, Linge District, Central Aceh District. In the document of Integrated Livestock Proposal Ketapang (2010), there are $\pm 2,000 \mathrm{Ha}$ of open land which is owned by Central Aceh Regency Government. Judging from Topography, this land is mostly vegetation in the form of natural grassland and alang-alang. Land in this location is generally very low fertility rate, so less suitable for horticultural crops and plantations.

The process of selecting households KPTK settlers through several stages. In the early stages, data were collected on the poor in 14 sub-districts in Central Aceh District. The data of poor people is obtained from the inventory of data recorded in Central Aceh BPS. The result of data inventory of BPS, there are 156 poor households which subsequently determined as prospective participants of settlement in KPTK.

In the next stage, prospective participants of KPTK settlers follow a selection stage consisting of: (a) interview selection; (b) breeding skills/knowledge test; (c) medical examinations and (d) psychological tests. At the interview selection stage each candidate was interviewed by several interviewers appointed by Bappeda Central Aceh. At the psychological test stage, there are some tested materials such as: translating visual images, matching numbers and words / phrases. This stage aims to determine the character of personality and motivation of prospective participants KPTK settlers who are represented by each head of the family. At this stage, Bappeda Aceh Tengah, which is responsible as the coordinator of the selection 
phase, appoints a third party, an independent institution to conduct the selection process.

The results of the selection stage, as many as 105 potential participants KPTK settlers passed the selection. In the next stage, each candidate who passes the selection shall be verified in the form of direct review, to assess the level of validity of the data previously collected. The results of the verification stage, determined 100 poor households as participants of settlement in KPTK, while five poor households as the reserve participants. This reserve participant, intended whenever the change of the settler participant is required, then the backup participant shall be the successor of the successor in the order in which it is assigned.

To improve the motivation and skills of human resources, before being placed in the KPTK each participant of the settlers participated in livestock training and mental guidance. In this training, each resident household head is given material on basic knowledge of livestock and also explains the rules regarding rights and obligations while at the KPTK. This training aims to prepare the participants of settlers, either in the form of preparation of knowledge of farming, mental and motivation to be able to try in KPTK.

Determination of settler participants in KPTK is determined through Decree (SK) of Regent of Central Aceh, Number 349 Year 2005, About Determination of Farmer Farmer for Ketapang Integrated Livestock Area in Linge Sub-district, Central Aceh Regency. The Decision Letter (SK) stipulates the regulations which must be obeyed by the participants of KPTK settlement, in the form of: (a) the facilities provided are not occupied, managed and/or abandoned within 1 (one) month consecutively The Aceh Tengah Regency government will take up land, housing, pens, livestock and other such facilities; (b) are not permitted to conduct transactions on sale or resettlement and the like primarily for land for 10 (ten) years from placement, and (c) not allowed to exchange land and houses that have been distributed.

\section{Characteristics of Selected KPTK Settlers}

The characteristics of selected KPTK settlers are seen from several variables: (a) age of family head and family members; (B) the formal education level of the head of the family; And (c) the work of the head of household before settling in KPTK. Each variable will be discussed as follows.

(a) Age of Family Head and Family Members;

The family head of settler households at the time of KPTK occupies between 29 and 51 years. Based on the age group, most household heads were in the 31 to 40 age group, $53.73 \%$ of the respondents were head of household, followed by 41 to 50 age groups of $34.33 \%$ of the respondents. Viewed from the age group, the overall age of the household head falls within the productive life span. The age of the head of the household, in line with the intent of one of the objectives of the selection process, is to select the prospective settlers who are still within the productive life span. Assuming that the productive age group will affect the ability to work in meeting the needs of household life.

In the data age group of family members can be seen that most are at school age (6-15 years) that is as many as 176 people or $79.28 \%$ of the total family members of respondents. Family members at school age, dominated by women as many as 103 people or $58.52 \%$ of the school-aged family members.

This condition reflects that, in the development of KPTK, education facilities and infrastructure are needed, so that relocated settlers can access education facilities properly.

\section{(b) Level of Formal Family Head Education;}

Education is one indicator that can indicate the level of household welfare. Data on education is derived from formal education that has been achieved by the head of the household. From percentage data of education level of head of family can be seen that most is in education of elementary and junior high reach $76,12 \%$ from number of respondent head of household. Even those who did not attend school reached $17.91 \%$ of the respondents' heads of households.

This condition reflects that the education level of head of household in KPTK is still low. Thus, in the implementation of guidance and mentoring in KPTK, it takes infromal training which aims to 
increase knowledge from the household heads of household settlers.

(c) Household Head Work Before Living in KPTK;

The majority of respondents' household heads before settling in KPTK work as farm laborers. From the data of distribution of family head work, $52,99 \%$ from head of respondent family work as farm laborer / livestock, followed by construction worker $31,34 \%$ and trader / labor market equal to $11,19 \%$. This condition illustrates that most of the household heads are already accustomed to trying in the agricultural sector.

Distribution of the types of household heads prior to living in the KPTK is required as a preliminary description in planning the proper guidance and assistance to the settlers, including training in the nature of livestock technical as well as non-technical nature.

\subsubsection{Distribution of Productive Assets to Settlers}

In the initial implementation of the formation of KPTK, Central Aceh district government to distribute assets to each household earning settlers. The distribution of productive assets is the livelihood assets required for the settler's family of four assets: (a) natural resource capital assets; (b) financial capital assets; (c) social capital assets; (d) physical capital assets. The distribution of productive assets is described as follows.

(a) distribution natural resource capital assets;

In the distribution of natural resource capital assets, there are several types of assets provided to each settler household in KPTK, such as: (a) the distribution of land; (b) distribution of cattle; (c) distribution of grass seeds as animal feed; (d) distribution of plant seeds.

Each settler household receives an area of \pm 2 (two) hectares. This land is designated as a planting land of grass, planting land, and simple house and yard. Distribution of land on the basis of its designation: (a) for grass planting land (LU I) of \pm 1-1.2 hectares; (b) Planting land (LU II) of $0.3-0.5$ hectare; While the rest is designated as (c) simple home land and yard.
Cattle breeding business is a staple farming for settlers in KPTK. Each settler household receives a total of 15 - 16 cattle. The determination of the number of cows that settlers receive is based on the scale of the cattle breeding business. In a review of the Feasibility Studies for the Development of KPTK in Central Aceh (2004), recommended that each settler household receive 12 -15 head of cattle. The distribution of cattle to settlers is done gradually, from 2005-2012. Up to 2012, Central Aceh Regency Government has distributed cattle livestock assets of 1,617 cows, with 77 bulls and 1,540 cows.

In addition to the distribution of livestock assets, the Central Aceh government also distributes grass seeds as forage forage (HMT). Seedlings are planted on every business field (LU I) owned by KPTK settlers. Elephant Grass (pennisetum purpureum) is selected as the type of grass seeds developed in the field. Selection of elephant grass is based on the ability and endurance to grow on marginal land well.

(b) distribution financial capital assets;

The provision of life insurance to every settler household in KPTK is part of the distribution of financial capital assets. The provision of jadup is temporary, and will be stopped when the farming efforts are done to meet the needs of the settlers. The granting of the jadup shall be distributed to every settler household which has occupied each plot of Rp. 400,000 per month, from January to April 2007. In May 2007, the provision of jadup increased to Rp. 750,000 per month. In addition to the provision of jadup, every household gets the mobilization fee to move from the original to the KPTK. The mobilization fee was given $\mathrm{Rp}$. 200,000 per settler household.

(c) distribution social capital assets;

In the effort to achieve the objective of the KPTK development program, on March 23, 2007, a group of ketapang livestock farmers has been established "Gayo Great Farm" through a democratic process and has agreed on the Articles of Association and Bylaws (AD/ART) of the group. Each KPTK settler becomes a member of the group, and is obedient and adherent to the provisions set forth in the $\mathrm{AD} / \mathrm{ART}$ group.

(d) Distribution physical capital assets. 
In the distribution of physical capital assets, there are several types of assets distributed to each settler household in KPTK, such as: (a) the distribution of houses of residence; (b) distribution of pens and supporting equipment; And (c) the distribution of the hedge.

The Central Aceh Government distributes residential homes to every settler household in KPTK. The residential house is a semi-permanent house with partially concrete and boarded concrete, with cement floor, with size $\pm 36 \mathrm{~m} 2$. Each unit of the house consists of living room / family, 2 bedrooms, kitchen and equipped bathroom. In addition, every residence is also equipped with electricity and clean water facilities.

Construction of the house has been realized in the year 2005 as many as 100 units. In its implementation, the Central Aceh Public Works Department acts as the party responsible for the activities. The residential house is built on the lots owned by the settler household. The settlement settlement for the settlers is done through a draw process.

In supporting the livestock activities carried out by settlers, the government facilitated the cattle pens and their supporting equipment. Each livestock enclosure is built in settlement / settlement land adjacent to the grass planting field (LU I). The built enclosure has a colony cage model with a size of $24 \mathrm{~m}^{2}$. Each cage is equipped with a feeding and drinking place for cattle and cement floors. The government also provides the equipment required by settlers such as: hoes, skup, stroller and so on.

Every settler's land has been fenced around. The fence is made of living fences (ponies) and tied with barbed wire. This fencing aims to monitor cattle to keep out of the land location, and to keep other animals from entering and destroying crops.

\section{Conclusion}

KPTK development has become a commitment to alleviate poverty. This is found in the central Aceh district development planning system. However, in its implementation there are several advantages of its development, namely: (1) not rearranging programs / programs of related sectors; (2) from a technical point of view, some physical facilities such as roads, bridges and housing and settlement enclosures have been damaged and can not be used anymore.

\section{References}

Abustan. (2010). Analisis Kerentanan dan Determinan Kemiskinan Berdasarkan Karakteristik Wilayah di Kabupaten Barru Provinsi Sulawesi Selatan. [Disertasi] Sekolah Pascasarjana Institut Pertanian Bogor.

[BPS] Badan Pusat Statistik. (2006). Analisis dan Perhitungan Tingkat Kemiskinan Tahun 2006. Badan Pusat Statistik, Jakarta.

Chambers, R. (1996). Pembangunan Desa Mulai dari Belakang. LP3ES. Jakarta.

Harniati. (2007). Tipologi Kemiskinan dan Kerentanan Berbasis Agroekosistem dan Implikasinya pada Kebijakan Pengurangan Kemiskinan.[Disertasi] Sekolah Pascasarjana Institut Pertanian Bogor.

[IFAD] International Fund for Agricultural Development. 2011. Rural Poverty Report 2011.

http://www.ifad.org/rpr2011/report/e/overvie w.pdf. Diakses: 29 September 2012.

Papilaya, E.C. dan Sugihen, B.G. (2006). Akar dan Strategi Pengentasan Kemiskinan di Kota Ambon, Maluku dan Kabupaten Balemo, Gorontalo. Jurnal Penyuluhan. Desember 2006, Vol. 2, No.4.

Susilo, Y.H., Agus S., David K. (2007). Penyebab Kemiskinan Masyarakat Tani (Studi di Dusun Ngebrong, Desa Tawangsari, Kecamatan Pujon, kabupaten Malang). Jurnal of Indonesian AppliedEconomics, Vol: 1, No. 1. Oktober 2007.

World Bank. 2012. Regional Aggregation Using 2005 PPP and \$1.25/day poverty line. http://iresearch.worldbank.org/PovcalNet/ind ex.htm?1. Diakses: 28 September 2012.

Wollenberg. E. 2004. Mengapa Kawasan Hutan Penting Bagi Penanggulangan Kemiskinan di Indonesia?. CIFOR, Jakarta. 